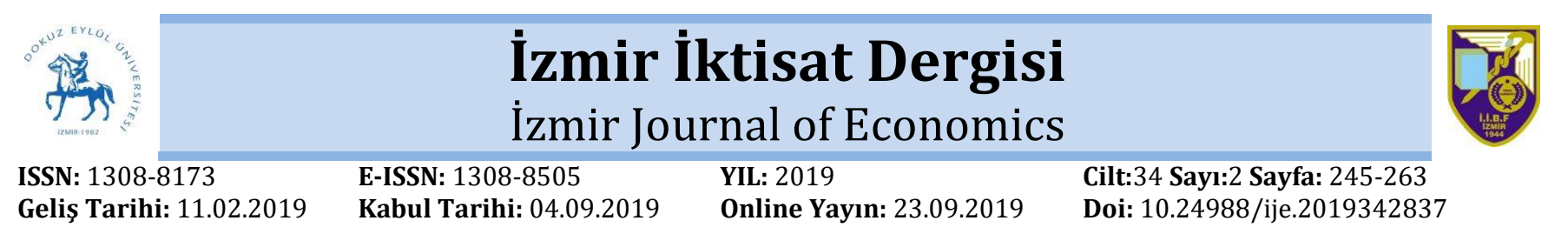

\title{
Kamu ve Özel Sektör Yatırımlarının Dinamik Etkileri: Altı Gelişmiş Ülke VAR Örneği
}

Oğuz TÜMTÜRK ${ }^{1}$

\begin{abstract}
Özet
Bu çalışma Fransa, Almanya, Japonya, Belçika, Birleşik Krallık ve ABD gelişmiş ülkelerinden yola çıkarak kamu ve özel sektör yatırımlar arasındaki ilişkiyi incelemekte, ayrıca kamu ve özel sektör yatırımlarının üretim ve istihdam üzerindeki etkilerini Vektör Otoregresyon (VAR) yöntemi kullanarak analiz etmektedir. Ekonomi literatürü genel olarak kamu yatırımlarının özel sektör yatırımlarına olan katkısını ve ekonomik aktivite üzerindeki etkilerini incelerken, bu çalışma özel sektör yatırımlarının kamu yatırımları ve ekonomik aktivite üzerindeki etkilerini de değerlendirmektedir. Çalışmada elde edilen bulgular, kamu yatırımlarının özel sektör yatırımlarının oluşumunu katkıda bulunabildiğini, ancak bunun tersinin geçerli olmadı̆̆ını ortaya koymaktadır. Yani, özel sektör kamu sektörü sermaye oluşumuna katkıda bulunmamaktadır. Bunun yanında, özel sektör yatırımlarının üretim ve istihdam üzerindeki etkileri, kamu yatırımlarının aynı değişkenler üzerindeki etkilerinden her zaman daha büyük olmaktadır. Son olarak ise elde edilen sonuçlar, kamu yatırımlarının çalışmada kullanılan diğer değişkenlere göre dışsal olduğu varsayımı altında, değişkenlerin alternatif VAR sıralamalarına karşı duyarlı değildir.
\end{abstract}

Anahtar kelimeler: Kamu Yatırımları, Özel Yatırımlar, Üretim, İstihdam

Jel Kodu: E22, E23, E62

\section{Dynamic Effects of Public and Private Investments: VAR Evidence from Six Advanced Economies}

Abstract

This paper investigates the long-term dynamic relationship between public and private investments and evaluates their impacts on economic activity in six advanced economies; France, Germany, Japan, Belgium, the United Kingdom and United States by a VAR framework. The related literature mostly considers the contribution of public investment to the formation of private investment and economic activity. This paper also evaluates the other way around: impacts of private investment on the formation of public investment and economic activity. Orthogonal identification assumptions are imposed to have an interpretable causal impulse-response functions. The empirical results provide evidences that public investment significantly contributes to private investment; however, the reverse is not true. That is, there is no any support for the hypothesis that private capital is also a crucial factor that drives public capital formation. Additionally, private investment always contributes more to output growth and employment than public investment. Finally, the empirical results are not sensitive to the alternative VAR orders of the variables under the assumption that public investment is exogenous with respect to other variables employed in this study.

Keywords: Public Investment, Private Investment, Production, Employment Jel Codes: E22, E23, E62

\section{INTRODUCTION}

The issue of whether public capital has an impact on the economic activity and formation of private capital has been a long-term discussion and generated a great deal of interest among economists. ${ }^{2}$ Theoretical literature admits that there is no clear-cut relationship between public and private investment. For example, a public investment may crowd out private investment when two types of investment substitutes. Then, public investment is expected to reduce private sector outputs. Conversely, if two types of investment are

\footnotetext{
${ }^{1}$ Dr. Öğr. Üyesi, Ordu Üniversitesi, İktisadi ve İdari Bilimler Fakültesi,Ünye / ORDU, e-mail: oguz.tumturk@gmail.com ORCID:0000-0002-1935-0858

${ }^{2}$ Economic activity refers both output and employment conditions of a country.
} 


\section{O. TÜMTÜRK}

complements, a public investment may crowd in private sector which suggests that public investments stimulate private sector activities. Since the magnitude of these effects is theoretically debatable, the macroeconomic impacts of public investments on different key variables can only be resolved empirically. Crowding-out hypothesis, in general, reflects the negative impacts of expansionary fiscal policies on private sector. Expansionary government policies may crowd out the private sector due to an increase in one of the three factors: interest rates, taxes and inflation tax. If, for example, public investment is financed by borrowing, rising interest rate may reduce the amount of credits available in the market. Increasing tax rate, on the other hand, produces an adverse effect by both rising costs of inputs of private sector and reducing total demand of goods and services. Finally, if public investment is carried out by printing money or inflation tax, then elevated uncertainty in the economy reduces expected returns of private sector. Therefore, each different financial source of public investment may dampen private sector activities. Conversely, public sector may also crowd in private sector as public sector produces positive externalities by constructing highways, ports, airports, railways and various infrastructure facilities for the use of private sector. Namely, the produced goods and services by public sector allow private firms to increase their marginal productivities and have broader access to domestic and foreign markets. Also, when two types of investments are complements, then the output produced by public sector directly enters the production function of private sector as an additional factor and leads to increases in private outputs.

This paper analyzes the empirical long-term dynamic relationship between public and private investments and evaluates their impacts on economic activities in six advanced economies: France, Germany, Japan, Belgium, the United Kingdom (UK) and United States (US). The related literature mostly evaluates the contribution of public investment on the formation of private capital and economic activity. This paper also evaluates the other way around: the impact of private investment on the formation of public capital and economic activity. Shortly, I address the following questions: 1) Does public investment crowd out private investment? 2) Does public investment affect output and employment level? 3) Does public and private investment produce equal impacts on economic activities? 4) What is the role of private investment in the formation of public investment? The macroeconomic dynamic effects of investments are investigated by a vector autoregressive (VAR) framework for several reasons. First, the theoretical literature in general has not been quite successful to offer an appropriate structural economic models that investigate public investment decisions. Conversely, the VAR framework is empirically considered to be quite successful when dynamic relationships among investment variables are not analyzed by fully-specified structural models. Namely, unlike conventional structural macro models, VAR approach provides a theoryfree method in the sense that it does not necessitate much knowledge to investigate the factors influencing the variables in the model.

Second, unlike single equation static production function approach employed by Aschauer (1989), Munnell (1990) and many others, dynamic feedbacks and interdependencies between public and private investments are required to use dynamic approaches. As mentioned above, public sector investment can induce private investment. However, an increase in private investment in response to a public investment shock may also produce positive externalities for public sector. For example, private investment stimulated by a shock in public investment can expand current tax base and provides more favorable conditions 
for public sector. Hence, a positive shock to innovations in public investment may produce contemporaneous positive impact on private investment (direct effect); additionally, private investment which evolves in response to positive externalities produced by public sector may incentivize public investments in the subsequent period (indirect effect). Consequently, one can trace these dynamic feedbacks and interdependencies in the VAR system. Finally, VAR models can easily capture the investigated dynamic interactions among investment variables by rationally imposed identifying assumptions. For example, our observations suggest that public sector does not react contemporaneously to change in private sector innovations due to time lags in government decision-making. However, private sector responds contemporaneously to a shock in innovations of public investment. When identifying innovations in the VAR model, mutually uncorrelated economic shocks are separated from the VAR innovations by imposing orthogonal identification assumptions to have an interpretable causal impulseresponse functions. The long-term elasticities, on the other hand, are obtained from the orthogonalized impulse-response functions.

The remainder of the article is organized as follows. In section 2, the theoretical and empirical literature are briefly reviewed. Section 3 includes methodological approach, orthogonal identification assumptions, and data. While empirical results are reported and analyzed in Section 4, conclusions are drawn in Section 5.

\section{LITERATURE}

In the literature, contribution of public investment to private investment and output is mostly estimated by a single equation static neoclassical production function approach or multivariate dynamic VAR framework. This section provides brief summary for the related literature.
Since the works by Aschauer (1989), there have been large body of literature investigating the effects of public capital formation on private output using production function approach. Aschauer concluded that nonmilitary public capital stock is a crucial factor in determining productivity than nonmilitary or military spending in the US. Specifically, core infrastructure facilities are found to be most powerful engine for productivity. He estimated that an increase in public capital elevates productivity by 0.3 percent. By using the same methodology, Munnell (1990) also found similar results by Aschauer. She estimated that one percent increase in nonmilitary public capital raises productivity by 0.31 to 0.39 percent. Tatom (1991), on the other hand, criticized Aschauer and Munnell's findings. He claimed that positive and significant effect of public capital on private output is likely to spurious since the data have stochastic trends; however, they are estimated in level. He employed first difference of the variables in the production function, and concluded that the impact of public capital on private output is not statistically significant. Evans and Karras (1994) used panel data estimation of Cobb-Douglas production function for the 48 US states, and investigated contribution of public capital to private output. They corrected the misspecifications of previous studies, and found evidence that government educational services are productive; however, the other government activities are not found to be productive. Overall, they suggested that the productivity of government capital is often negative and significant.

However, many authors argued that extensively used static single equation production function approach cannot capture the dynamic feedbacks between private and public investments. Hence, they proposed to use dynamic multivariate times series framework. For example, Pereira (2000) analyzed the effects of public investment on private sector in the US 


\section{TÜMTÜRK}

by VAR framework. He used Cholesky decomposition to identify VAR residuals and estimated cumulative orthogonalized impulseresponse functions to calculate the elasticities with respect to change in public investment. He found that the private investment elasticity is 0.2290 which suggests that aggregated public investment contributes to private investment. Additionally, private employment elasticity is estimated at 0.0073 while private output elasticity is 0.0425 . They also found that each type of public investment has a positive impact on private output. Mittnik and Neumann (2001) investigated the dynamic relationship between public investment and output using VAR approach similar to Pereira (2000). They analyzed six advanced countries in their studies and concluded that an increase in public investment leads to GDP growth. They also reported that specific country results do not support the crowding-out effect of public investments on private investments. Blanchard and Perrotti (2002) explored the dynamic impacts of shocks in public sector on US economic activity in the postwar period by using structural VAR framework. Their results revealed that public spending shocks exert a positive effect on output. They also indicated that increases in government spending reduce private investment.

Voss (2002) analyzed the crowding-out hypothesis using data for both the US and Canada by orthogonalized VAR. According to the baseline model that investment share variables are ordered last, he found that public investment crowds out private investment. Additionally, his results were robust with respect to alternative order that investment share variables are ordered first. Kamps (2005) analyzed the productivity of public capital for 22 OECD economies. He concluded that public capital significantly drives output growth for the majority of the countries; however, his results did not produce positive employment effects.
Afonso and Aubyn (2009) evaluated macroeconomics impacts of public and private investment using 17 developed economies using VAR analysis similar to Mittnik and Neumann (2001) and Pereira (2000). With respect to public investment impulses, their results revealed that eight economies produce both crowding-in effect and positive output growth. While five economies have both crowding-out effect and negative output growth, crowding-out and positive output elasticities prevail in four economies. However, these estimates are mostly insignificant. Unlike public investments, private investment impulses always contribute positively to output growth.

Bom and Ligthart (2009) evaluated the effect of public capital on private output using metaanalytical techniques. By composing 67 studies for the 1983-2008 period, they concluded that short-term average output elasticity of public capital is 0.085 and significant. In the long-term, by considering to spillover effects, the impact of public capital to private output raises by a factor of three. Dreger and Reimers (2016) analyzed the long-term relationship between two types of investments with panel cointegration analysis in the euro area. They indicated that deviations from a long-term relationship between the public and private capital stocks drives private investment, and insufficiency of public investment may reduce private investment and output growth in the euro area. Abiad, Furceri and Topalova (2016) analyzed the impacts of public investment in 17 OECD advanced countries. They concluded that public investment crowds in private investment and leads to increases in output and employment level.

\section{METHODOLOGY AND DATA}

Since VAR estimates and inferences are sensitive to identifying an appropriate VAR specification, one must consider a wide range of choices: stationarity properties of the variables, existence of the deterministic components, the 
number of lags selected, and model diagnostic checks.

\subsection{Stationarity}

Phillips-Perron (1988) unit root test is performed to investigate the stationarity properties of the variables. The test uses NeweyWest (1987) heteroscedasticity and autocorrelation consistent (HAC) covariance estimator to make Dickey Fuller (ADF) (1979) test statistics robust to possible serial correlation. The results in Appendix, Table A.1. reveal that all series are integrated of order one, I(1).

\subsection{Specification of the VAR model}

For each economy, four-variable VAR model that contains real public investment (rgov), real private investment (rpriv), real GDP (rgdp), unemployment level (unemp) is conducted. ${ }^{3}$ All variables are taken in logarithmic form. Real GDP and unemployment data are also included in order to compute long-term cumulative elasticities of output and unemployment with respect to innovations in investment variables. The variables in the VAR model are the first differences of the logarithms of the original variables. ${ }^{4}$ Since all variables are integrated of order one, the first-differenced variables are all stationary. The VAR model is estimated using first-differenced stationary data in line with standard procedure in the literature.5,6 Simply, the VAR model without exogenous variables is formed by the following logged first-differenced variables:

$$
\mathrm{Xt}_{\mathrm{t}}=\left(\Delta \operatorname{lrgov}_{\mathrm{t}} \Delta \operatorname{lipriv}_{\mathrm{t}} \Delta \operatorname{lrgdp}_{\mathrm{t}} \Delta \text { lunemp }_{\mathrm{t}}\right)^{\mathrm{T}}
$$

A pth-order unrestricted VAR model in a reduced form with four endogenous variables is

\footnotetext{
${ }^{3}$ GDP deflator is used to express variables in real terms.

4 The letter "l" represents the logarithm of each variable. Since the first difference of the logarithm of a variable is approximately equal to its percentage change, the variables in (1) can be considered as percentage change in investments, output, and unemployment, that is, growth rates of the original variables.
}

given by linear functions of the lagged values of the endogenous variables and innovations as:

$$
\begin{aligned}
& \mathrm{x}_{\mathrm{t}}=\gamma+\mathrm{A}_{1} \mathrm{x}_{\mathrm{t}-1}+\mathrm{A}_{2} \mathrm{x}_{\mathrm{t}-2}+\cdots+\mathrm{A}_{\mathrm{p}} \mathrm{x}_{\mathrm{t}-\mathrm{p}}+\mathrm{u}_{\mathrm{t}}, \\
& \text { and } \mathrm{E}\left(\mathrm{u}_{\mathrm{t}} \mathrm{u}_{\mathrm{t}}^{\mathrm{T}}\right)=\Sigma
\end{aligned}
$$

Where $\mathrm{x}_{\mathrm{t}}$ is a $4 \mathrm{x} 1$ vector of endogenous variables, $\gamma$ is a $4 \times 1$ vector of constant parameters, $A_{1}$ through $A_{p}$ are $4 \times 4$ matrices of autoregressive coefficients, and $\mathrm{u}_{\mathrm{t}} \sim \mathrm{N}(0, \Sigma)$ is a $4 \times 1$ vector of the VAR innovations (disturbances). Innovations are uncorrelated with their own past values and uncorrelated with all of the right hand-side variables. However, they may be contemporaneously correlated with each other, that is, the variancecovariance matrix of innovations $\Sigma$ is nondiagonal suggesting that $\mathrm{E}\left(\mathrm{u}_{\mathrm{t}} \mathrm{u}_{\mathrm{s}}^{\mathrm{T}}\right) \neq 0$ for $\mathrm{t} \neq \mathrm{s}$. This is a quite standard problem in VAR analysis, and it requires to use some identifying assumptions to have interpretable causal impulse-responses as discussed in the next section. The optimum number of lag differences of the VAR model, on the other hand, is determined in two steps. First, the number of lag is selected by Schwarz's Bayesian information criterion (SBIC). However, if the multivariate Lagrange multiplier test results suggest autocorrelation at the selected SBIC lag level, then the number of lag is elevated appropriately until autocorrelation is removed. Exogenous deterministic components of the VAR model are also selected by SBIC.

Some diagnostics are also checked to find out a suitable VAR model. First, the appropriate VAR model necessitates the stability of the system. All inferences after VAR require that variables are covariance stationary, that is, time independency of the first two moments of the

\footnotetext{
${ }^{5}$ I did not chose to use Johansen's framework (1988, 1991) including cointegration and maximum-likelihood estimation of appropriate error correction representation of the VAR model since economic theory does not suggest a long-term relationship among the original variables.

${ }^{6}$ Estimation of the VAR model (1) was performed by using Stata 11 econometrics package program.
} 


\section{TÜMTÜRK}

variables in $\mathrm{x}_{\mathrm{t}}$. If the VAR is stable, the impulseresponses decay over time since shocks have temporary impacts on the differenced series. As shown by Hamilton (1994), stability of the VAR requires modulus of the all eigenvalues are strictly less than one. Additionally, multivariate Jarque-Bera (1987) normality tests for normally distributed innovations are performed. If the innovations in $u_{t}$ are not normally distributed, the parameter estimates are still consistent, but confidence intervals around estimates are not reliable. When the model is large relative to sample size, standard errors of the impulseresponse functions should be calculated by bootstrapping VAR innovations. Finally, Granger non-causality test described by Granger (1969) is conducted to investigate the interdependency among the variables.

\subsection{Identification of the VAR model innovations}

Since the VAR model has large number of coefficients to interpret, orthogonalized impulse-response analysis are performed to investigate the effects of innovations in public and private investments. An impulse-response function traces the reaction of variables in the VAR model due to a one-time unit exogenous shock to one of the innovations in $u_{t}$. If innovations are not contemporaneously correlated, then one can measure the reaction of variable k over time in response to a shock in the innovation to variable $r$ while holding the other innovations constant. However, if innovations exhibit strong correlation, an exogenous shock to one of the innovations in the model also presents information about the innovations of other variables. That is, it is impossible to shock one innovation with other innovations are fixed. When $\Sigma$ is nondiagonal, standard impulseresponse analysis cannot produce causal interpretable results due to the common component in the innovations.

Now, consider the VAR model (1). The VAR innovations can be assumed to be a linear transformation of mutually uncorrelated economic shocks $\varepsilon_{\mathrm{t}}$ such that:

$$
\mathrm{u}_{\mathrm{t}}=\mathrm{P} \varepsilon_{\mathrm{t}} \text { where } \mathrm{E}\left(\mathrm{u}_{\mathrm{t}} \mathrm{u}_{\mathrm{t}}^{\mathrm{T}}\right)=\Sigma=\mathrm{PP}^{\mathrm{T}} \text {. }
$$

$A_{i}$ and $\Sigma$ can be econometrically identified without any further identification assumptions by using simple regressions. However, all elements in matrix $\mathrm{P}$ are required to be uniquely identified to have an interpretable causal impulse-response function. In a n-variable VAR, symmetric variance-covariance matrix $\Sigma$ has $\left(n^{2}+n\right) / 2$ independent elements while $P$ has $n^{2}$ unknowns. Hence, $\left(n^{2}-n\right) / 2$ additional assumptions are needed to recover all elements of P. Without these identification assumptions, the mutually uncorrelated economic shocks $\varepsilon$ from the VAR innovations cannot be uniquely separated. Sims (1980) proposed Cholesky Decomposition of $\Sigma$ to choose such a P. The unique lower triangular matrix $\mathrm{P}$ is called Cholesky factor of $\Sigma$. This process produces identity covariance matrix of $\varepsilon_{t}$ since

$$
\begin{aligned}
\mathrm{E}\left(\varepsilon_{\mathrm{t}} \varepsilon_{\mathrm{t}}^{\mathrm{T}}\right)=\mathrm{E}\left(\mathrm{P}^{-1} \mathrm{u}\left(\mathrm{P}^{-1} \mathrm{u}\right)^{\mathrm{T}}\right) & =\mathrm{P}^{-1} \mathrm{E}\left(\mathrm{uu}^{\mathrm{T}}\right) \mathrm{P}^{\mathrm{T}-1} \\
& =\mathrm{P}^{-1} \Sigma \mathrm{P}^{\mathrm{T}-1}=\mathrm{I}_{\mathrm{n}} .
\end{aligned}
$$

Now, variance covariance matrix of uncorrelated shocks $\varepsilon$ are diagonal, and each orthogonalized shock has unit variance. Then, one can investigate the impacts of shocks over time to a particular innovation in ut. This whole scheme is known as "orthogonalization", and it produces orthogonalized impulse-response functions.

However, the choice of the order of the series in the VAR model (1) may affect results obtained from the orthogonalized impulse-response analysis due to Wold-ordering problem. Since orthogonal shocks are uniquely identified using Cholesky factor P based on the lower triangular identifying assumptions, the first variable in the order is contemporaneously unaffected by all other variables. That is, the variables are ordered from most to least exogenous. The order of the VAR model specified above $(\Delta \operatorname{lrgov}$, 
$\Delta$ lrpriv, $\Delta$ lrgdp, $\Delta$ lunemp) implies that public investment is exogenous with respect to private investment and economic activities. Namely, innovations in public investment affect private investment contemporaneously while any exogenous shock to innovations in private investment affects public investment series with one-period lag. ${ }^{7}$ There is a reason for making this assumption. One can reasonably consider that public sector reveals its investment decisions for the subsequent period in line with their budgetary planning, and private sector responds contemporaneously to innovations in public investment. However, as stated by Pereira (2000, p.515), public sector does not react within a same period to innovations in private sector due to the "time lags involved in information gathering and government decision-making". Similarly, a shock to innovations in private investment affects output and unemployment contemporaneously. Additionally, public investment variable is also exogenous with respect to output since governments operate public investments mostly to stabilize the output growth in line with the literature (Mittnik and Neumann (2001), Blanchard and Perotti (1999), Abiad et al. (2016), Afonso and Aubyn (2009)). ${ }^{8}$ With all these assumptions, all elements of Cholesky

\footnotetext{
7 The identification assumptions imposed here are in line with those made in Pereira (2000), Mittnik and Neumann (2001), Voss (2002), and Afonso and Aubyn (2009).

8 One can also consider that public investment is endogenous with respect to output shocks, that is, public investment contemporaneously evolves in response to output conditions. However, to exclude this effect, I separate output and employment shocks from public investment innovations by imposing identification restrictions on Cholesky factor P so that $a_{13}=a_{14}=0$.

${ }^{9}$ Since orhogonalized impulse-responses may be sensitive to order of variables in the VAR model, Pesaran and Shin (1998) offer generalized impulse-response functions (GIRF) which are unaffected by alternative order of the variables. Their method computes the impact of shocks by assuming each variable are respectively ordered first in a Cholesky order. For example, suppose the first order is the same as above $\mathrm{x}_{\mathrm{t}}=\left(\Delta \operatorname{lrgovt}, \Delta \operatorname{lrprivt}_{\mathrm{t}}, \Delta \operatorname{lrgdp} \mathrm{t}, \Delta\right.$ lunemp $\left._{\mathrm{t}}\right)$.
}

factor $\mathrm{P}$ above the main diagonal are zero $\left(a_{12}=\right.$ $a_{13}=a_{14}=a_{23}=a_{24}=a_{34}=0$ ), and reduced form innovations $u_{t}$ to each endogenous variables can be specified respectively as: ${ }^{9}$

$$
\begin{aligned}
& \mathrm{u}_{1 \mathrm{t}}=\mathrm{a}_{11} \varepsilon_{1 \mathrm{t}} \\
& \mathrm{u}_{2 \mathrm{t}}=\mathrm{a}_{21} \varepsilon_{1 \mathrm{t}}+\mathrm{a}_{22} \varepsilon_{2 \mathrm{t}} \\
& \mathrm{u}_{3 \mathrm{t}}=\mathrm{a}_{31} \varepsilon_{1 \mathrm{t}}+\mathrm{a}_{32} \varepsilon_{2 \mathrm{t}}+\mathrm{a}_{33} \varepsilon_{3 \mathrm{t}} \\
& \mathrm{u}_{4 \mathrm{t}}=\mathrm{a}_{41} \varepsilon_{1 \mathrm{t}}+\mathrm{a}_{42} \varepsilon_{2 \mathrm{t}}+\mathrm{a}_{43} \varepsilon_{3 \mathrm{t}}+\mathrm{a}_{44} \varepsilon_{4 \mathrm{t}} .
\end{aligned}
$$

\subsection{Data}

The data used are quarterly and seasonally adjusted for the sample periods reported in Table 1. All data but GDP deflator are obtained from OECD Quarterly National Accounts sources as available from their internet site. The investment data used in this study are current prices gross fixed capital formation and deflated by GDP deflator. Harmonized unemployment data are expressed in level terms (persons). ${ }^{10}$ Similarly, Gross Domestic Product at current prices is also deflated by GDP deflator. GDP deflator data are obtained from Federal Reserve Bank of St. Louis (FRED) as available from their internet site. Table 1 reports the average investment shares and output growth rates. As seen in Table 1, average shares of private investments are always much greater than average shares of public investments. The US has the highest average growth rates with

This implies that public investment is not contemporaneously affected by all other variables. Now, I change the order so that private investment leads others. Now, private investment is not instantaneously affected by public investments and other two variables. However, these two Cholesky orders based on two different identifying assumptions are "extreme" as suggested by Kim (2012) in the sense that they contradict each other. I choose to use orthogonalized impulse-responses with the Cholesky order ( $\Delta$ lrgov, $\Delta$ lrpriv, $\Delta$ lrgdp, $\Delta$ lunemp) since the previously imposed identification assumptions on this order that are made based on the economic rationale and observations seem more plausible with respect to "extreme" GIRF identification.

10 OECD (2018) defines harmonized unemployment as "the unemployed as people of working age who are without work, are available for work, and have taken specific steps to find work." 


\section{O. TÜMTÜRK}

second largest public investment share while Japan has the lowest average growth rate with largest public investment share.

Table 1: Average investment shares and output growth rates

\begin{tabular}{|c|c|c|c|c|c|}
\hline \multirow[b]{2}{*}{ Countries } & \multirow[b]{2}{*}{$\begin{array}{l}\text { Sample } \\
\text { Period }\end{array}$} & \multirow[b]{2}{*}{$\begin{array}{l}\text { Average } \\
\text { Growth }\end{array}$} & \multicolumn{3}{|c|}{ Investment as a Ratio of GDP } \\
\hline & & & $\begin{array}{c}\text { Public } \\
\text { Investment }\end{array}$ & $\begin{array}{c}\text { Private } \\
\text { Investment }\end{array}$ & $\begin{array}{c}\text { Total } \\
\text { Investment }\end{array}$ \\
\hline Germany & $\begin{array}{l}\text { 1991Q2- } \\
\text { 2018Q1 }\end{array}$ & 0.354 & 2.3 & 18.7 & 21.0 \\
\hline US & $\begin{array}{l}\text { 1987Q2- } \\
\text { 2018Q1 }\end{array}$ & 0.693 & 4.2 & 17.1 & 21.4 \\
\hline Japan & $\begin{array}{l}\text { 1994Q2- } \\
\text { 2018Q1 }\end{array}$ & 0.250 & 6.2 & 18.8 & 25.1 \\
\hline France & $\begin{array}{l}\text { 1983Q1- } \\
\text { 2018Q1 }\end{array}$ & 0.452 & 4.0 & 17.7 & 21.7 \\
\hline UK & $\begin{array}{l}\text { 1967Q4- } \\
\text { 2018Q2 }\end{array}$ & 0.531 & 2.4 & 15.3 & 17.8 \\
\hline Belgium & $\begin{array}{l}\text { 1995Q2- } \\
\text { 2018Q1 }\end{array}$ & 0.441 & 2.2 & 20.1 & 22.3 \\
\hline
\end{tabular}

\section{EMPIRICAL RESULTS}

\subsection{VAR specification and forecast error decomposition of investment variations}

Table 2 reports the VAR specification and diagnostic tests results. As seen in Table 2, joint Jarque-Bera (1987) normality tests reject the null of normality. Relatively small sample size and non-normality of the VAR innovations require to employ bootstrapping method to detect the statistical significance of the impulseresponse functions more precisely. Additionally, the specified VAR models are stable for each economy. The last four columns in Table 2 report Granger non-causality test results. The null of non-causality was rejected in 16 out of the 24 cases at ten percent significance level. These results provide evidences that there is strong interdependence among the variables. More importantly, test results reveal the exogeneity of public investment with respect to other variables. For example, Granger noncausality tests of private investments with respect to public investment and other two are rejected for all economies while Granger noncausality tests of public investments are only rejected for Japan and Germany at ten percent significance level. This provides empirical evidence that public investment is more exogenous than private investment. Consequently, non-causality test results empirically support the economic rationale behind the identifying assumptions in the preceding section.

Table 3 reports the forecast error variance decompositions (FEVD) at different forecast horizons. The proportions in the table indicate how much of the variability in investment variables is attributable to each orthogonalized shock to the other variables. At different forecast horizons, innovations to public investments are second important source of variation in private investment except for Japan and Belgium. Even though these results reveal an evidence on existence of interaction between public and private investments, further analysis is required to find out the direction of the interaction. For example, the innovation to public investments 
may draw resources away from the private sector, which is simply a crowding-out. This may also imply that innovation to public investments produces some externalities and incentivizes private sector firms to raise their own levels of capital investments, which is simply a crowdingin. Additionally, in response to innovations in output, private investments always produce greater variations relative to those obtained from public investment which are mostly around zero. This may provide evidence in favor of the accelerator mechanism of private investments. ${ }^{11}$ Moreover, innovations to output are second strongest source of the variation in private investment in Japan and Belgium.

Table 2: Specification of VAR order and diagnostic checks

\begin{tabular}{|c|c|c|c|c|c|c|c|c|}
\hline & \multirow{2}{*}{\multicolumn{3}{|c|}{ VAR Order $\mathbf{p}^{\mathbf{a}}$}} & \multicolumn{5}{|c|}{ Granger Non-Causality (Prob. Value)b } \\
\hline & & & & \multicolumn{5}{|c|}{ Dependent Variables } \\
\hline & 1 & 2 & 3 & $\begin{array}{c}\text { Normality } \\
\text { Test } \\
\text { (Prob. } \\
\text { Value)c } \\
\end{array}$ & $\Delta$ lrgov & $\Delta$ lrpriv & $\Delta \operatorname{lrgdp}$ & slunemp \\
\hline Germany & $\begin{array}{l}33.40 \\
(0.00)\end{array}$ & $\begin{array}{l}13.77^{*} \\
(0.61)\end{array}$ & & 0.00 & 0.02 & 0.00 & 0.01 & 0.21 \\
\hline US & $\begin{array}{l}51.14 \\
(0.00)\end{array}$ & $\begin{array}{l}31.84 \\
(0.01)\end{array}$ & $\begin{array}{l}18.32^{*} \\
(0.30)\end{array}$ & 0.00 & 0.14 & 0.00 & 0.00 & 0.00 \\
\hline Japan & $\begin{array}{l}29.19 \\
(0.02) \\
\end{array}$ & $\begin{array}{l}18.98^{*} \\
(0.26)\end{array}$ & & 0.000 & 0.00 & 0.03 & 0.12 & 0.00 \\
\hline France & $\begin{array}{l}28.78 \\
(0.02)\end{array}$ & $\begin{array}{c}20.59 * \\
(0.19)\end{array}$ & & 0.00 & 0.50 & 0.05 & 0.39 & 0.00 \\
\hline UK & $\begin{array}{c}15.36^{*} \\
(0.49)\end{array}$ & & & 0.000 & 0.88 & 0.00 & 0.14 & 0.00 \\
\hline Belgium & $\begin{array}{l}18.89 * \\
(0.27)\end{array}$ & & & 0.000 & 0.63 & 0.00 & 0.04 & 0.02 \\
\hline
\end{tabular}

Notes: a An asterisk indicates the VAR order chosen. A large enough value is assigned on $\mathrm{p}$ so that $\mathrm{u}_{\mathrm{t}}$ is free from autocorrelation. The null of multivariate LM autocorrelation test indicates that there is no first order autocorrelation. The test statistic follows as an asymptotic chi-square distribution with $\mathrm{n}^{2}=16$ degrees of freedom. The VAR models for France, Japan and the US include linear trend component while the UK, Germany, and Belgium only contain a constant.

b The null of Granger non-causality test indicates that the remaining three variables jointly do not Granger-cause the named dependent variable in that column. The Granger non-causality Wald test follows an asymptotic chi-square distribution.

c I reported only joint Jarque-Bera test results. I also used single-equation Jarque-Bera test for each endogenous variable respectively, and vast majority of the tests reject normality. The results are available upon request.

11 The accelerator effect states that growth of the economy yields positive impacts on private fixed capital formation. If private investors in an economy see a rise in total demand due to an increase in national income, they raise their existing productive capacity and spend more on capital goods. 


\section{O. TÜMTÜRK}

Table 3: Forecast error variance decomposition of public and private investments

Notes: FEVD requires orthogonalizing the $u_{t}$ innovations. Sum of the contribution of each orthogonalized innovation to investment variables may not be zero due to rounding. 1,8 and 20 are the quarterly forecast horizons. 


\subsection{Impacts of innovations in public investment: Long-term cumulative elasticities}

This section evaluates the impacts of one standard deviation shock in the rate of growth of public investment on the growth rate of the private investment and economic activity. The long-term cumulative orthogonalized responses of private investments with respect to a one standard deviation shock in public investment are plotted in Appendix, Figure A.1.12 Convergence, in general, is achieved around ten quarters (2.5 years). The grey area indicates 90 percent bootstrap confidence bands around impulse-responses. The estimated impulseresponse functions show relatively smooth progress in France, Japan and the US. Immediate reactions are positive in France, Germany and the US while the UK and Belgium produce negative immediate effect. However, there is not any contemporaneous effect in Japan. The short and long-term cumulative reactions are positive for three of the six countries, France, Germany and Japan whereas they are negative in the US, the UK and Belgium. Table 4 reports long-term cumulative responses of all variables with respect to orthogonalized shock to innovation in public investment and 90 percent confidence bands around the responses.

Table 4: Long-term cumulative responses with respect to public investment

\begin{tabular}{|c|c|c|c|c|}
\hline & Response Variables & Lower Bound & Cumulative Response & Upper Bound \\
\hline \multirow{4}{*}{ Germany } & $\Delta$ lrgov & .009726 & .012882 & .016038 \\
\hline & $\Delta$ lrpriv & .001029 & .004163 & .007296 \\
\hline & $\Delta \operatorname{lrgdp}$ & .000201 & .001294 & .002388 \\
\hline & $\Delta$ lunemp & -.017543 & -.010413 & -.003284 \\
\hline \multirow{4}{*}{ US } & $\Delta$ lrgov & .006931 & .009223 & .011514 \\
\hline & $\Delta$ lrpriv & -.009867 & -.005138 & -.00041 \\
\hline & $\Delta \operatorname{lrgdp}$ & -.001217 & .000028 & .001274 \\
\hline & Slunemp & -.002948 & .007969 & .018886 \\
\hline \multirow{4}{*}{ Japan } & slrgov & .007024 & .0105 & .013976 \\
\hline & $\Delta$ lrpriv & -.001396 & .002646 & .006688 \\
\hline & $\Delta \operatorname{lrgdp}$ & -.000262 & .001001 & .002264 \\
\hline & Slunemp & -.007341 & -.001922 & .003497 \\
\hline \multirow{4}{*}{ France } & $\Delta$ lrgov & .007143 & .010195 & .013246 \\
\hline & $\Delta$ lrpriv & .000207 & .004431 & .008655 \\
\hline & $\Delta \operatorname{lrgdp}$ & .000016 & .001247 & .002478 \\
\hline & Slunemp & -.012762 & -.006792 & -.000823 \\
\hline \multirow{4}{*}{ UK } & $\Delta$ lrgov & .022441 & .028424 & .034407 \\
\hline & $\Delta$ lrpriv & -.008675 & -.004352 & -.000029 \\
\hline & $\Delta \operatorname{lrgdp}$ & -.001732 & -.000684 & .000364 \\
\hline & $\Delta$ lunemp & -.002943 & .003393 & .00973 \\
\hline \multirow{4}{*}{ Belgium } & $\Delta$ lrgov & .013692 & .021182 & .028672 \\
\hline & $\Delta$ lrpriv & -.004687 & -.00193 & .000827 \\
\hline & $\Delta \operatorname{lrgdp}$ & -.001265 & -.000352 & .000562 \\
\hline & Slunemp & -.005985 & -.000969 & .004046 \\
\hline
\end{tabular}

Notes: Table reports point estimates to a one standard deviation innovation in public investment and 90 percent confidence intervals. The bold cumulative responses are statistically significant at the 90 percent level.

12 As suggested by Pereira (2000, p.516), long-term is defined as the time horizon which cumulative impulseresponse functions converge. 


\section{O. TÜMTÜRK}

The long-term cumulative elasticities with respect to public investment are computed as suggested by Pereira and Flores (1999). These elasticities calculate the long-term cumulative change in the growth rate of the variables in $\mathrm{xt}$ with respect to long-term cumulative change in the growth rate of public investment once all the dynamic feedback effects in the system are triggered by one standard deviation public investment shock. Three different elasticities are calculated: i) Private investment elasticity ii) Output elasticity, and iii) Unemployment elasticity. ${ }^{13}$ For example, long-term private investment elasticity is calculated by the ratio between the cumulative change in the growth rate of private investment and the cumulative change in the growth rate of public investment.

Suppose one-time unit exogenous shock to innovation in public investment occurs. Table 5 reports long-term cumulative elasticities with respect to public investment. First, consider the positive private investment elasticities. Positive private investments elasticities in France, Japan and Germany imply that public investments crowd in private investments. These elasticities are significant in France and Germany since 90 percent confidence intervals containing the responses of two types of investment variables do not include zero values. Complementarity effect of public investments on private investments significantly exerts positive output elasticities, with the exception of Japan. Additionally, significant negative unemployment elasticities in France and Germany indicate that public investment reduces unemployment. Shortly, one can generalize these results so that whenever public investment significantly crowds in private investment, its contribution to output and employment becomes positive.

Table 5: Long-term cumulative elasticities with respect to public investment

\begin{tabular}{cccc}
\hline & Private Investment & Output & Unemployment \\
\hline Germany & $\mathbf{0 . 3 2 3}$ & $\mathbf{0 . 1 0 0}$ & $\mathbf{- 0 . 8 0 8}$ \\
\hline US & $\mathbf{- 0 . 5 5 7}$ & 0.003 & 0.864 \\
\hline Japan & 0.252 & 0.095 & -0.183 \\
\hline France & $\mathbf{0 . 4 3 4}$ & $\mathbf{0 . 1 2 2}$ & $\mathbf{- 0 . 6 6 6}$ \\
\hline UK & $\mathbf{0 . 1 5 3}$ & -0.024 & 0.119 \\
\hline Belgium & -0.091 & -0.016 & -0.045 \\
\hline
\end{tabular}

Note: The bold elasticities are statistically significant at the 90 percent level.

Now, consider the negative private investment elasticities. Public investment crowds out private investment in the US, UK and Belgium. When judged by 90 percent confidence intervals, they are all significant with the exception of Belgium. The long-term output elasticity in the UK and Belgium are negative. ${ }^{14}$

\footnotetext{
13 Output and unemployment elasticities contains both direct and indirect effects of public investment. Suppose a public investment shock hits the economies. Public investment contemporaneously reacts in response to the shock. Then, direct effect explains the impact of the change in public investment on output and unemployment. Indirect effect, on the other hand, refers the change in output and unemployment through evolution of private
}

Negative output elasticity indicates that increase in public investment in response to a public investment shock raises public output; however, decreasing private output as a result of crowding-out effect outweighs the increases in public output. ${ }^{15}$ Unlike the UK and Belgium, expansionary effect of public investments on

investment stimulated by a direct change in public investment.

${ }^{14}$ Khan and Umar $(1997$, p.72) state that if two types of investment are substitutes, then they may have a negative effect on growth. Additionally, Evans and Karras (1994), Afonso and Aubyn (2009) also provide evidence of negative output elasticities in their studies.

${ }^{15}$ Notice that these negative elasticities do not imply that total private output in an economy declines by more than 
output in the US is larger than the contractionary effect of private investments on output in response to a shock in public investment so that output elasticity is positive. However, both output and unemployment elasticities are insignificant in the UK, the US and Belgium since confidence intervals around output and unemployment responses always include zero value. ${ }^{16}$ Shortly, one can generalize these results so that whenever public investment crowds out private investment, it produces statistically insignificant output and unemployment elasticities. These results, overall, show the existence of both significant substitution and complementarity effects in the six advanced countries. However, output and unemployment responses with respect to public investment impulses produce significant elasticities only if crowding-in hypothesis is significantly valid.

\subsection{Sensitivity analysis}

When innovations in the VAR model is identified, public investment is ordered first, that is, innovations in public investment contemporaneously affect private investment and economic activities. The exogeneity of public investment with respect to the remaining variables is also supported by the empirical evidences obtained from Granger non-causality tests. In this section, I adhere to the assumption that public investment leads other variables, and investigate sensitivity of the results with respect to alternative order of the variables. Then, following orders are considered by switching the remaining variables:

$$
\begin{aligned}
& \mathrm{Xt}_{\mathrm{t}}=(\Delta \operatorname{lrgov}, \Delta \text { lrpriv }, \Delta \text { lunemp }, \Delta \text { lrgdp }) \\
& \mathrm{Xt}_{\mathrm{t}}=(\Delta \text { lrgov }, \Delta \text { lunemp }, \Delta \operatorname{lrgdp}, \Delta \text { lrpriv }) \\
& \mathrm{Xt}_{\mathrm{t}}=(\Delta \text { lrgov }, \Delta \operatorname{lrgdp}, \Delta \operatorname{lrpriv}, \Delta \text { lunemp })
\end{aligned}
$$

The estimated elasticities from the alternative orders are exactly the same as those obtained from the baseline order. Alternatively, if public investment is not ordered first, that is, one switches the order by relaxing the exogeneity assumption of public investment with respect to others, the results significantly change as it is usual in orthogonalized VAR analysis. However, one cannot gain any benefit from dropping this assumption as both empirical evidences and our economic observations confirm the exogeneity of public investment.

\subsection{Impacts of innovations in private investment: Long term cumulative elasticities}

This section evaluates the impacts of one standard deviation shock in the rate of growth of private investment on the growth rate of the public investment and economic activity. Longterm cumulative impulse-responses of public investments to a one standard deviation shock in private investment are plotted in Appendix, Figure A.2. The country specific cumulative impulse-responses show that there are no any immediate reactions for all countries since innovations in private investments does not produce contemporaneous effects on public investment. However, the short and long-run cumulative reactions are positive for three out of the six countries: France, Germany and the UK whereas they are negative for the remaining countries: the US, Japan and Belgium. Table 6 reports long-term cumulative responses of all variables with respect to orthogonalized shock to innovation in private investment with 90 percent bootstrap confidence bands.

The correspondent cumulative elasticities of private investments are computed in a way

${ }^{16}$ Insignificant output elasticity in the US does not confirm Ascauer (1989) and Munnell (1990)'s assertions that public investment is a significant factor driving output growth. 


\section{O. TÜMTÜRK}

analogous to innovation in public investments. These elasticities calculate the long-term cumulative change in the growth rate of the variables in $\mathrm{xt}$ with respect to long-term cumulative change in the growth rate of private investment once one standard deviation private investment shock hits the economies. Three different elasticities are calculated from the cumulative impulse-response functions: i. Public investment elasticity ii. Output elasticity, and iii) Unemployment elasticity. Now, suppose onetime unit exogenous shock to innovation in private investment occurs. Table 7 reports longterm cumulative elasticities.

Table 6: Long-term cumulative responses with respect to private investment

\begin{tabular}{|c|c|c|c|c|}
\hline & $\begin{array}{l}\text { Response } \\
\text { Variables }\end{array}$ & Lower Bound & $\begin{array}{l}\text { Cumulative } \\
\text { Response }\end{array}$ & Upper Bound \\
\hline \multirow{4}{*}{ Germany } & $\Delta$ lrgov & -.000423 & .002886 & .006195 \\
\hline & $\Delta$ lrpriv & .006303 & .010395 & .014487 \\
\hline & $\Delta \operatorname{lrgdp}$ & .001321 & .003037 & .004752 \\
\hline & $\Delta$ lunemp & -.023487 & -.013576 & -.003665 \\
\hline \multirow{4}{*}{ US } & $\Delta$ lrgov & -.003997 & -.001369 & .001258 \\
\hline & $\Delta$ lrpriv & .013071 & .017819 & .022566 \\
\hline & $\Delta \operatorname{lrgdp}$ & .002642 & .00396 & .005278 \\
\hline & $\Delta$ lunemp & -.046757 & -.03504 & -.023323 \\
\hline \multirow{4}{*}{ Japan } & $\Delta \operatorname{lrgov}$ & -.005979 & -.001316 & .003348 \\
\hline & $\Delta$ lrpriv & .008057 & .013673 & .019289 \\
\hline & $\Delta \operatorname{lrgdp}$ & .000851 & .002735 & .00462 \\
\hline & slunemp & -.02057 & -.012428 & -.004286 \\
\hline \multirow{4}{*}{ France } & $\Delta$ lrgov & -.002323 & .001157 & .004637 \\
\hline & $\Delta$ lrpriv & .008361 & .01382 & .019279 \\
\hline & $\Delta \operatorname{lrgdp}$ & .001854 & .003388 & .004922 \\
\hline & $\Delta$ lunemp & -.027074 & -.018793 & -.010511 \\
\hline \multirow{4}{*}{ UK } & $\Delta$ lrgov & -.002369 & .00153 & .005428 \\
\hline & $\Delta$ lrpriv & .011407 & .016535 & .021664 \\
\hline & $\Delta \operatorname{lrgdp}$ & -.000184 & .000934 & .002052 \\
\hline & Slunemp & -.017009 & -.009494 & -.001979 \\
\hline \multirow{4}{*}{ Belgium } & Alrgov & -.003388 & -.000753 & .001882 \\
\hline & $\Delta$ lrpriv & .005954 & .008035 & .010117 \\
\hline & $\Delta \operatorname{lrgdp}$ & -.000585 & .00024 & .00106 \\
\hline & $\Delta$ lunemp & -.008087 & -.003572 & .000943 \\
\hline
\end{tabular}

Notes: Table reports point estimates to a one standard deviation innovation in private investment and 90 percent confidence intervals. The bold cumulative responses are statistically significant at the 90 percent level.

Table 7: Long-term cumulative elasticities with respect to private investment

\begin{tabular}{cclc}
\hline & Public Investment & Output & Unemployment \\
\hline Germany & 0.2776 & $\mathbf{0 . 2 9 2 1}$ & $\mathbf{- 1 . 3 0 6 0}$ \\
\hline US & -0.0768 & $\mathbf{0 . 2 2 2 2}$ & $\mathbf{- 1 . 9 6 6 4}$ \\
\hline Japan & -0.0962 & $\mathbf{0 . 2 0 0}$ & $\mathbf{- 0 . 9 0 8 9}$ \\
\hline France & 0.0837 & $\mathbf{0 . 2 4 5 1}$ & $\mathbf{- 1 . 3 5 9 8}$ \\
\hline UK & 0.0925 & 0.0564 & $\mathbf{- 0 . 5 7 4 1}$ \\
\hline Belgium & -0.0937 & 0.0298 & -0.4445
\end{tabular}

Note: The bold elasticities are statistically significant at the 90 percent level. 
Table 7 reports that public investment elasticities of private investments are always insignificant, that is, private investment does not significantly contribute the evolution of public investment. Second, private investment exerts positive significant effect on output with the exception of the UK and Belgium. More importantly, the magnitude of the significant output elasticities indicate that private investment contributes more to output growth than public investment. Third, unemployment elasticities with respect to private investments are always negative. When judged by 90 percent confidence interval, unemployment elasticities are significant in Germany, the US, Japan, France and the UK. Similar to output elasticities, private investment produces much larger significant positive impact on employment than public investment.

\section{CONCLUSION}

This paper investigates the empirical longterm dynamic relationship between public and private investments and compares the effects of two types of investments on economic activity using VAR framework for six advanced economies. In the literature, there are two main empirical approaches estimating the effects of public investment on private investment and economic activities; single equation production function approach and VAR approach. In this study, I employ VAR analysis in order to capture dynamic feedbacks and interdependencies between public and private investments. Mutually uncorrelated economic shocks are uniquely separated from VAR innovations by imposing lower triangular identification assumptions. The main results can be summarized as follows:

1) In response to public investment shocks;

i. The elasticities of private investments with respect to public investments are mostly significant with the exception of Japan and Belgium. However, public investment crowds in private investment in France and Germany while its contribution to private investment is negative in the US and UK. These results suggest the existence of both significant substitution and complementarity effects in the six advanced countries, and neither crowding-in nor crowding-out hypotheses dominates.

ii. Even though the private investment elasticities are mostly significant, public investment produces positive impact on output and employment in two economies, France and Germany. These results support the assertion that public investment is significant factor driving output growth with only modest evidences. Additionally, whenever public investment significantly crowds in private investment, its contribution to output and employment becomes significantly positive; however, this is not true when public investment crowds out. Namely, whenever public investment crowds out private investment, its contribution to output and employment becomes statistically insignificant.

iii. Results are not sensitive to the alternative orders of the variables under the assumption that public investment is exogenous with respect to the others.

2) In response to private investment shocks;

i. Unlike the public investment shocks, private investment never significantly contributes to public investment. Hence, there is no any support for the hypothesis that private capital is also a crucial factor that drives public capital formation.

ii. Private investment always produces positive effect on output and employment. Unlike the public investment shocks, private investment mostly produces significant output and unemployment elasticities. While unemployment elasticities are all significant with the only exception of Belgium, output elasticities are significant in Germany, the US, Japan, and France. 


\section{O. TÜMTÜRK}

iii. Overall, there is a substantial difference in the effect of public and private sector investment on output and employment. Private investment produces much larger significant positive impact on output and employment than public investment. When conducting economy policies, these differences should be taken into account. Policymakers should take measures to provide more favorable conditions for private sector such as lower tax rates, more predictable macroeconomic environment, infrastructure facilities and advanced financial sector.

\section{REFERENCES}

Abiad, A., Furceri, D., and Topalova, P. (2016). The Macroeconomic Effects of Public Investment: Evidence from Advanced Economies. Journal of Macroeconomics, $50,224-240$.

Afonso, A., and Aubyn, M.S. (2009). Macroeconomic Rates of Return of Public and Private Investment: Crowding-In and Crowding-Out Effects. The Manchester School Supplement, 77, 21-39.

Aschauer, D. (1989), "Is Public Expenditure Productive? Journal of Monetary Economics, 23, 167-200.

Blanchard, O., and Perotti, R. (2002). An Empirical Characterization of the Dynamic Effects of Changes in Government Spending and Taxes On Output. The Quarterly Journal of Economics, 117(4), 1329-1368.

Bom, P.R.D., and Ligthart, J.E. (2009). How Productive Is Public Capital? A MetaRegression Analysis. Georgia State University Working Paper 09-12, Atlanta.

Dickey, D. A., and Fuller, W. A. (1979). Distribution of The Estimators for Autoregressive Time Series with a Unit Root. Journal of the American Statistical Association, 74, 427-431.

Dreger, C., and Reimers, H.E. (2016). Does Public Investment Stimulate Private Investment? Evidence for The Euro Area. Economic Modelling, 58, 154-158.
Evans, P., and Karras, G. (1994). Are Government Activities Productive? Evidence from a Panel of U.S. States. The Review of Economics and Statistics, 76(1),1-11.

Granger, C. W. J. (1969). Investigating Causal Relations by Econometric Models and Cross-Spectral Methods. Econometrica, 37, 424-438.

Hamilton, J. D. (1994) Time Series Analysis. Princeton: Princeton University Press.

Jarque, C. M., and Bera, A. K. (1987). A Test for Normality of Observations and Regression Residuals. International Statistical Review, 55 (2), 163-172.

Johansen, S. (1988). Statistical Analysis of Cointegration Vectors. Journal of Economic Dynamics and Control, 12, 231254.

Johansen, S. (1991). Estimation and Hypothesis Testing of Cointegration Vectors in Gaussian Vector Autoregressive Models. Econometrica, 59, 1551-1580.

Kamps, C. (2005). The Dynamic Effects of Public Capital: VAR Evidence for 22 OECD Countries. International Tax and Public Finance, 12(4), 533-558.

Khan, M.S., and Kumar, M.S. (1997). Public and Private Investment and The Growth Process in Developing Countries. Oxford Bulletin of Economics and Statistics, 59(1), 69-88. 
İzmir İktisat Dergisi (İzmir Journal of Economics) , Yll:2019 Cilt:34 Sayı:2 ss. 245-263

Kim, H. (2012). Generalized Impulse Response Analysis: General or Extreme?". Auburn Economics Working Paper Series 2012-04, Department of Economics, Auburn University.

Mittnik, S., and Neumann, T. (2001). Dynamic Effects of Public Investment: Vector Autoregression Evidence from Six Industrialized Countries. Empirical Economics, 26, 429-446.

Munnell, A.H. (1990). Why Has Productivity Growth Declined? Productivity and Public Investment. New England Economic Review, Jan./Feb, 3-22.

Newey, W. K., and West, K. D. (1987). A Simple, Positive Semi-Definite, Heteroskedasticity and Autocorrelation Consistent Covariance Matrix. Econometrica, 55, 703708.

OECD (2018), Harmonised Unemployment Rate (HUR),https://data.oecd.org/unemp/har monised-unemployment-rate-hur.htm (Accessed on 01 December 2018)
Pereira, A. (2000). Is All Public Capital Created Equal?. The Review of Economics and Statistics, 82(3), 513-518.

Perreria, A., and Flores De Frutos, R. (1999). Public Capital Accumulation and Private Sector Performance. Journal of Urban Economics, 46, 300-322.

Pesaran, M. H., and Shin, Y. (1998). Generalized Impulse Response Analysis in Linear Multivariate Models. Economics Letters, 58, 17-29.

Sims, C. A. (1980). Macroeconomics and Reality. Econometrica, 48, 1-48.

Phillips, P. C. B., and Perron, P. (1988). Testing for A Unit Root in Time Series Regression. Biometrika, 75, 335-346.

Tatom, J. A. (1991). Public Capital and Private Sector Performance. Federal Reserve Bank of St. Louis Review, May/June, 3-15.

Voss, G. (2002). Public and Private Investment in The United States and Canada. Economic Modelling, 19, 641-664.

\section{APPENDIX}

Table A.1: Phillips-Perron unit root test results

\begin{tabular}{|c|c|c|c|c|c|c|c|c|c|}
\hline & \multicolumn{7}{|c|}{ Test Statistic $^{\mathbf{a}}$} & \\
\cline { 2 - 11 } & lrgov & $\Delta$ lrgov & lrpriv & $\Delta$ lrpriv & lrgdp & $\Delta$ lrgdp & lunemp & $\Delta$ lunemp & Result \\
\hline France & -2.00 & -8.82 & -0.48 & -4.97 & -1.96 & -6.08 & -2.82 & -5.49 & $\mathrm{I}(1)$ \\
\hline Germany & -1.49 & -13.67 & -1.33 & -9.42 & -0.14 & -7.74 & 0.06 & -3.09 & $\mathrm{I}(1)$ \\
\hline Japan & -1.57 & -9.28 & -1.87 & -6.18 & -1.44 & -8.56 & -0.78 & -5.93 & $\mathrm{I}(1)$ \\
\hline US & -0.44 & -14.72 & -1.22 & -7.14 & -1.47 & -10.55 & -2.66 & -6.65 & $\mathrm{I}(1)$ \\
\hline UK & -1.14 & -14.14 & -2.25 & -14.85 & -1.45 & -6.01 & -1.64 & -4.51 & $\mathrm{I}(1)$ \\
\hline Belgium & -2.44 & -20.95 & -1.25 & -12.44 & -2.10 & -4.94 & -2.29 & -11.30 & $\mathrm{I}(1)$ \\
\hline
\end{tabular}

Notes: \%5 critical value is -2.887 for France; -2.890 for Germany; -2.894 for Japan; -2.883 for the US; -2.888 for the UK; and -2.897 for Belgium. Newey-West lag truncation parameter is three for Japan and Belgium while it is four for France, Germany, the UK and US. 


\section{TÜMTÜRK}


Note: Figures report cumulative orthogonalized private investment responses to a one standard deviation shock in public investment and 90 percent confidence intervals (grey area).

Figure A.1: Responses of Private Investments with Respect to Shocks in Public Investment 
İzmir İktisat Dergisi (İzmir Journal of Economics) , Yll:2019 Cilt:34 Sayı:2 ss. 245-263


Note: Figures report cumulative orthogonalized public investment responses to a one standard deviation shock in private investment and 90 percent confidence intervals (grey area).

Figure A.2: Responses of Public Investments with Respect to Shocks in Private Investment 